Research Article

\title{
Experimental Study on the Effect of Compaction Work and Defect on the Strength of Soil-Rock Mixture Subgrade
}

\author{
Xin Yan $\mathbb{D}^{1},{ }^{1,2}$ Wei Zhan $\mathbb{D}^{1,2}$ Zhi Hu $\mathbb{D}^{1,2}$ Yiqiang Yu $\mathbb{D}^{1,2}$ and Danqiang Xiao $\mathbb{D}^{1,2}$ \\ ${ }^{1}$ Key Laboratory of Road and Bridge Detection and Maintenance Technology Research of Zhejiang Province, \\ Hangzhou 310023, China \\ ${ }^{2}$ Zhejiang Scientific Research Institute of Transport, Hangzhou 310023, China \\ Correspondence should be addressed to Wei Zhan; zhanwei@zju.edu.cn
}

Received 2 March 2021; Revised 7 April 2021; Accepted 28 May 2021; Published 8 June 2021

Academic Editor: José António Fonseca de Oliveira Correia

Copyright (C) 2021 Xin Yan et al. This is an open access article distributed under the Creative Commons Attribution License, which permits unrestricted use, distribution, and reproduction in any medium, provided the original work is properly cited.

\begin{abstract}
Soil-rock mixture is a common filling material for earth dam and subgrade. In this study, research concerned on the evolution law of engineering characteristics of soil-rock mixture under different factors and the effect of defect on subgrade strength, and geotechnical tests were carried out to analyze the influence of different factors on engineering characteristics of soil-rock mixture in the study, and the physical model was carried out to analyze the effect of different compaction works on the resilient modulus, and the influence of defect on the strength was explored by manually preset loose body. The test results showed that (1) when the soil-rock mixture was graded, $P=78$, the moisture content was $14 \%$, and the engineering characteristics were optimal; (2) there was a positive correlation between compaction times and resilient modulus, and the stress transferred from the subgrade to soil was linearly distributed under the good condition of compactness; and (3) the existence of loose body not only reduces the modulus of resilience but also affects the stress transfer; the larger the loose body, the lower the resilient modulus and the greater the stress transfer.
\end{abstract}

\section{Introduction}

Soil-rock mixture is a complex discontinuous medium material, which was composed of stones, soils as filling components, and pores. It has the characteristics of complex geological origin, diverse composition, and extremely uneven soil and rock particles across multiple orders of magnitude scales and structures [1-4]. Because soil-rock mixture is easy to get, it is often used for roadbed filling in construction [5]. The rock with large size in soil-rock mixture and its engineering properties are between ordinary rock and soil [6,9], and its compaction characteristics and mechanical characteristics determine the safety and stability of pavement $[8,9]$.

Rock content has a great influence on the physical and mechanical properties and permeability of soil-rock mixture [10-12], the rock content of soil-rock mixture is generally $25-75 \%$, and when the rock content is not within this range, the physical and mechanical properties of soil-rock mixture are usually only affected by soil or rock [13, 14]. A large number of laboratory model tests and numerical experiments have proved that the size, shape, distribution, and other mesostructural characteristics of rock will have an impact on the physical and mechanical characteristics of soil-rock mixture [15-17]. Xu et al. [18] explored the influence of different rock contents on strength and failure characteristics of soil-rock mixture by the triaxial test, and the experiment showed that the deviatoric stress ratio and friction strength of soil-rock mixture increased with the increase of rock content.

In addition to rock content, the influence of rock particle size, water content, and other parameters on the engineering characteristics of soil-rock mixture is also considerable $[4,19,20]$. The change of water content will affect the shear strength of soil, thus affecting the bonding strength of soilrock interface. Zhao et al. [21] studied the shear strength change of soil-rock mixture under different factors through laboratory tests, and it was found that the effect degree of 
water content on the shear strength of soil-rock mixture is just next to the rock content.

According to previous research studies, it can be found that the shear strength of soil-rock mixture is mainly affected by rock content, water content, gradation, and other factors, and the main testing methods include the triaxial test and large-scale shear test [22-24]. However, shear strength cannot fully characterize the engineering characteristics of soil-rock mixture. Therefore, in order to fully describe the engineering characteristics of the soil-rock mixture, it is necessary to test the compaction characteristics, resilient modulus, and other properties of the soil-rock mixture $[25,26]$. Zhang et al. [27] proposed a new method based on the theory of elastic waves to evaluate the compaction quality of soil-rock mixture accurately and efficiently.

Meanwhile, the uniform distribution of soil-rock mixture often existed in the construction, and the existence of uniform soil-rock mixture subgrade would lead to uneven stress distribution, resulting in uneven settlement of the subgrade, and lead to the failure of the road structure, so it is necessary to understand the effect of loose material on the strength of subgrade. Zhou et al. [28] carried out the compaction simulating and comparative test of compaction quality indexes to explore the relationship between deformation law and compaction degree of soil-rock mixture.

The study obtained the optimum gradation and water content of soil-rock mixture through the compaction test, resilient modulus test, and direct shear test, which provided the optimum material for the physical model, and the physical model test was established to explore the effect of compactness on the subgrade strength, so as to explore the evolution law between strength and compaction of soil-rock mixture and study the influence of local inhomogeneity on subgrade strength, which could provide theoretical basis for engineering construction and later restoration.

\section{Selection of Test Material}

Soil-rock mixture is composed of soil and rock, and its engineering characteristics are determined by the properties of the two parts. According to the research of Guo [29], particle size of $5 \mathrm{~mm}$ is the demarcation particle size, particle size greater than $5 \mathrm{~mm}$ is coarse grain, particle size less than $5 \mathrm{~mm}$ is fine grain, and particle content greater than $5 \mathrm{~mm}$ is denoted as $P_{5}$. The content of coarse particles is closely related to the compactness and shear strength of soil-rock mixture.

When the $P_{5}^{\prime} 30 \%$, the coarse particle is completely enveloped by fine material and the engineering properties of soil-rock mixture are determined by the fine particle; in addition, the permeability coefficient is slightly lower and other engineering properties are improved. When $30 \%{ }^{\prime} P_{5}^{\prime} 70 \%$, coarse particle and fine particle fill each other, with the increase of the content of coarse particle, and engineering properties of soil-rock mixture show the characteristics of coarse particle. When $P_{5} \exists 70 \%$, fine particle cannot be filled with pore, and the engineering characteristics of soil-rock mixture depend on the characteristics of the coarse particle at this time.
According to Specifications for Design of Highway Subgrades (JTGD30-2015) and Test Methods of Soils for Highway Engineering (JTG3430-2020), coarse soil such as well-graded gravel soil and sandy soil should be selected as the filling material for subgrade $(0.8-1.5 \mathrm{~m}$ below the pavement), with the maximum particle size of not more than $40 \mathrm{~mm}$. Therefore, the oversized particle needed to be replaced in this study, and $10 \%, 25 \%, 54 \%, 64 \%, 78 \%$, and $90 \%$ were selected for $P_{5}$ preliminarily.

Tailor proposed the empirical formula for ideal particle grading of soil that is easy to compact as follows:

$$
p_{i}=\left(\frac{d_{i}}{d_{\max }}\right)^{n} \times 100
$$

where $p_{i}$ is the mass percentage (\%) less than a certain particle size; $d_{i}$ is the particle size $(\mathrm{mm}) ; d_{\max }$ is the maximum particle size (mm); and $n$ is the gradation index. When $n=0.25 \sim 0.5$, the compactness of soil is the optimum. In this study, when $P_{5}=78 \%, n=0.445$, the gradation is good, so $P_{5}=78 \%$ is selected as the optimal gradation and the median gradation value in the laboratory test in study. Considering the distribution range of $P_{5}$ and the value of $n, P_{5}=90 \%$ and $P_{5}=54 \%$ were taken as the upper and lower limits of gradation, and then, the gradation of $P_{5}=78 \%$ was taken as the median value to determine three gradations. The gradation curves are shown in Figure 1. The gradation is given in Table 1.

\section{Geotechnical Tests}

According to the three selected gradations, in order to obtain the influence of gradation and moisture content on the engineering characteristics of soil and stone mixes, compaction tests, cyclic compression tests, and large direct shear tests were conducted to obtain the optimum gradation and optimum moisture content. And the material used in the cyclic compression test and direct shear test was the specimen that has completed the compaction in the compaction test. The geotechnical test equipment is shown in Figure 2.

According to the compaction test, the relationship curve between water content and dry density of soil-rock mixture can be obtained, as shown in Figure 3. It can be seen that there is a parabolic relationship between dry density and moisture content of soil-rock mixture, and the optimum moisture content of gradation 1 is $13.2 \%$ and the maximum dry density is $1.623 \mathrm{~g} / \mathrm{cm}^{3}$; the optimum moisture content of gradation 2 is $14.0 \%$ and the maximum dry density is $1.650 \mathrm{~g} / \mathrm{cm}^{3}$; the optimum moisture content of gradation 3 is $14.5 \%$ and the maximum dry density is $1.870 \mathrm{~g} / \mathrm{cm}^{3}$.

Through the cyclic compression tests, the stress-strain curves of different gradations at different moisture contents were obtained. As shown in Figure 4, the curve distribution of compressive stress and compressive strain was basically the same. After the first loading and unloading, the residual strain was larger. After the second loading and unloading, the curve distribution of stress and strain was basically the same. There was basically no residual deformation, and it presented as the elastic deformation. Resilient modulus of 


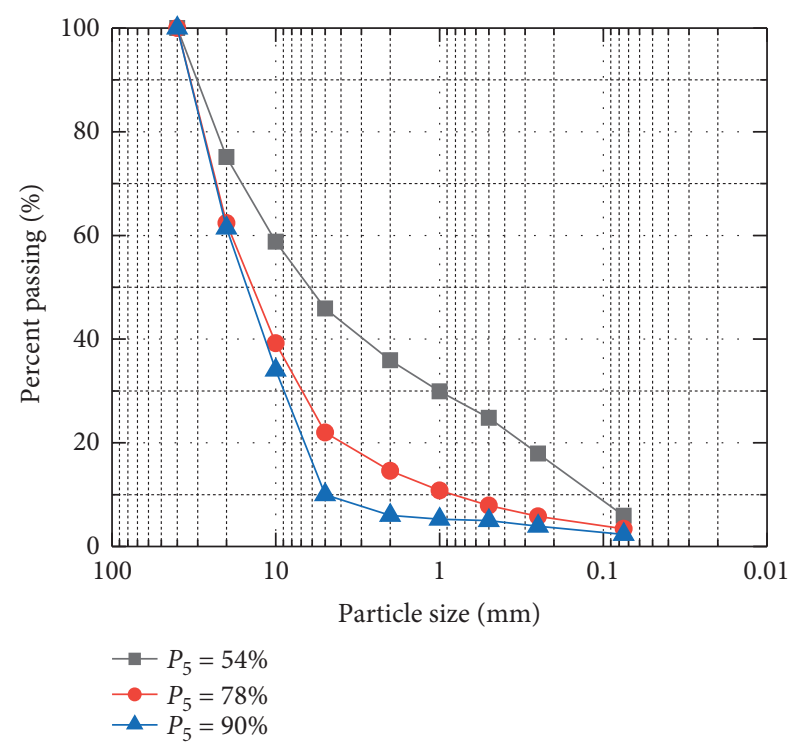

Figure 1: The gradation curves of soil-rock mixture.

TABLE 1: The selected gradation of soil-rock mixture.

\begin{tabular}{lccc}
\hline Particle diameter $(\mathrm{mm})$ & & $P_{5}$ & \\
& $54 \%$ & $78 \%$ & $90 \%$ \\
\hline $40 \sim 20$ & 24.9 & 37.6 & 38.6 \\
$20 \sim 10$ & 16.3 & 23.2 & 27.4 \\
$10 \sim 5$ & 12.9 & 17.2 & 24 \\
$5 \sim 2$ & 10 & 7.4 & 4 \\
$2 \sim 1$ & 6 & 3.8 & 0.73 \\
$1 \sim 0.5$ & 5.09 & 2.9 & 0.26 \\
$0.5 \sim 0.25$ & 6.89 & 2.1 & 1.09 \\
$0.25 \sim 0.075$ & 11.99 & 2.4 & 1.61 \\
$0.075 \sim 0$ & 5.93 & 3.4 & 2.31 \\
\hline
\end{tabular}

soil-rock mixture with different gradations under different moisture contents can be obtained by the cyclic compression test. The equation to calculate the resilient modulus is as follows:

$$
E_{e}=\frac{\Delta p}{\Delta \varepsilon_{e}},
$$

where $E_{e}$ is the resilient modulus of soil, $\Delta p$ is effective stress increment, and $\Delta \varepsilon_{e}$ is vertical elastic strain increment.

As shown in Figure 5, the relationship between resilient modulus and moisture content was approximately parabolic. By fitting the relationship between resilient modulus and moisture content, it can be obtained that the resilient modulus of gradation 1 is the highest when the moisture content is $11.9 \%$, which is $292.6 \mathrm{MPa}$. The resilient modulus of gradation 2 is the highest at $13.3 \%$ moisture content, which is $259.0 \mathrm{MPa}$, and that of gradation 3 is the highest at $14.8 \%$ moisture content, which is $243.9 \mathrm{MPa}$.

The variation of cohesion and friction angle of soil-rock mixture at different moisture contents can be obtained by the large-scale direct shear test, as shown in Figure 6. It can be found that when the moisture content was $14 \%$, the cohesion and friction angles of the soil-rock mixture with gradation 2 were the largest, indicating that the shear strength of the soil-rock mixture was the highest at this time. Therefore, the engineering characteristics of gradation 2 with $14 \%$ moisture content were the best, and the soil-rock mixture was selected as the physical model material in the study.

\section{Physical Model Test}

4.1. Test Setup. The physical model test was designed according to the structure type of Yuhang section of G320 highway. This section was constructed according to the firstgrade highway standard. The site of $150 \mathrm{~cm} \times 400 \mathrm{~cm}$ in the middle of the model was selected as the test area, as shown in Figure 7. The test area was cut down $50 \mathrm{~cm}$ as the soil surface. The test area was divided into three blocks, as shown in Figure 8. In order to simulate the uneven of subgrade, different compaction degrees were set in three regions when layered paving. The test material adopted the soil-rock mixture with gradation 2 as the test material. The gradation curve is shown in Figure 9.

To ensure the consistency of pavement conditions, C20 concrete was used to equivalent the water stable layer in the model test, and the stiffness EI was used to equivalently convert the thickness of concrete to $0.2 \mathrm{~m}$ (water stable layer: $E=1500 \mathrm{MPa}$, concrete: $\left.E=2.55 \times 10^{4} \mathrm{MPa}\right)$. A movable pavement model $(1 \mathrm{~m} \times 1 \mathrm{~m} \times 0.2 \mathrm{~m})$ was made in the laboratory, so that it can move to different regions, and the pavement is shown in Figure 10.

4.2. Test Equipment. The test mainly determined the subgrade quality by testing the resilient modulus of the pavement. The resilient modulus is tested by the bearing plate method, as shown in Figure 11. In the process of resilient modulus testing, the soil pressure cell placed on the top of soil foundation was used to test the pressure change on the top of soil foundation. The soil pressure cell used in the test is shown in Figure 12.

The soil pressure cells were laid on the surface of the soil foundation, and the test area was divided into three regions. The center of each region was arranged with one soil pressure cell, and the arrangement position of the soil pressure cell is shown in Figure 13.

\subsection{Test Procedures}

(1) After the excavation of the test site, the resilient modulus of the soil foundation was tested, and the average value of the test twice was taken as the reference value of the resilient modulus of the soil foundation.

(2) The subgrade was constructed in three layers, and the test area was divided into three regions. After the paving of each layer of material, the vibration compactor was used to compact the region 1 for 12 times, the region 2 for 8 times, and the region 3 for 4 times. The thickness of each layer was $15 \mathrm{~cm}$, and the moisture content was controlled at about $14 \%$. The 

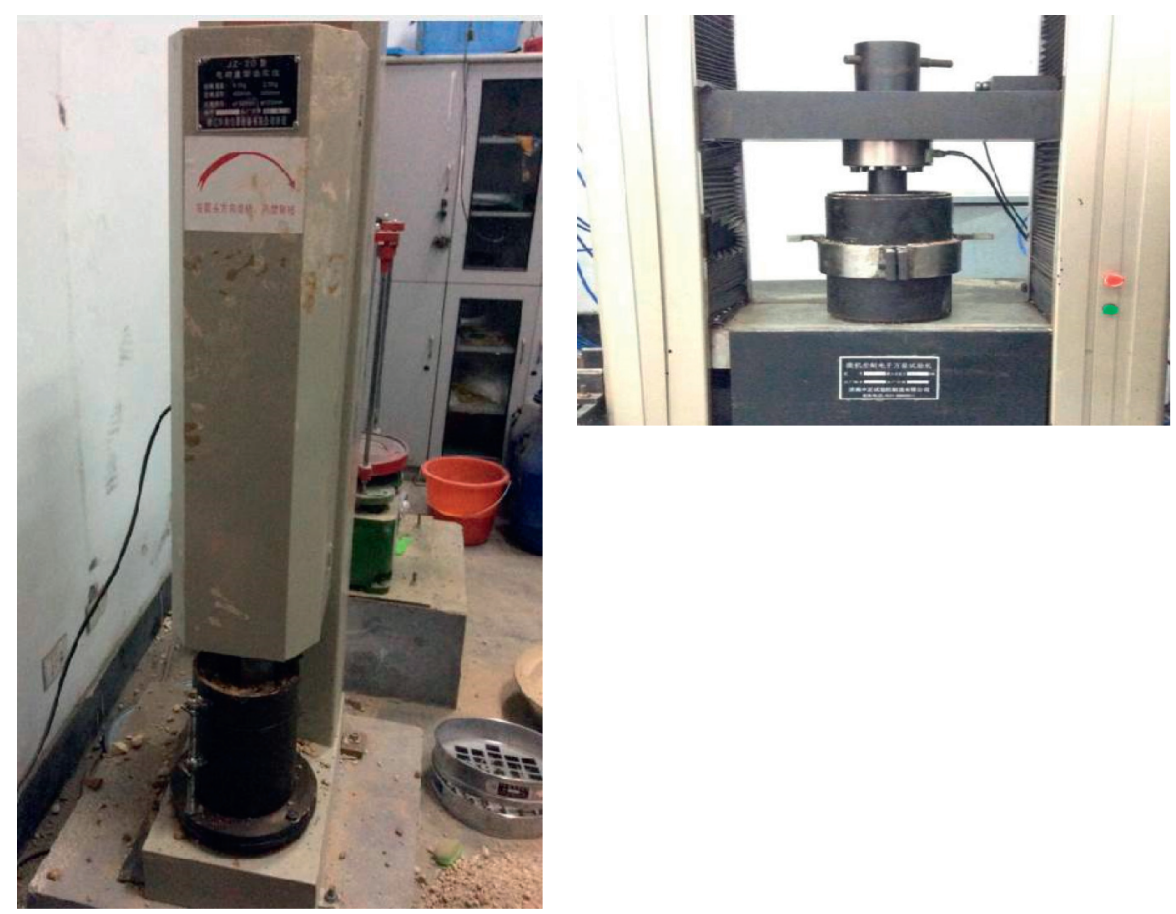

(a)

(b)

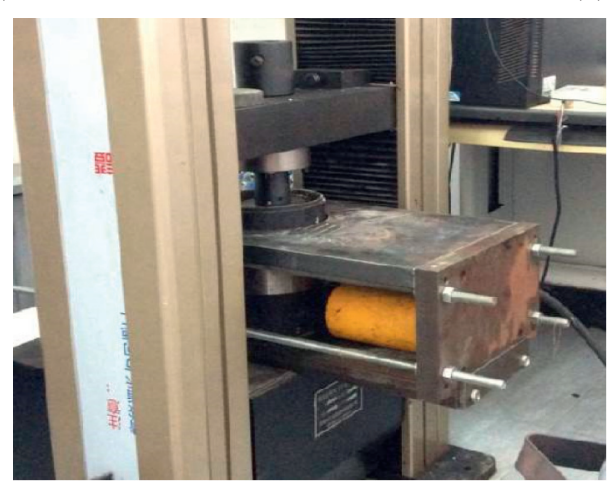

(c)

FIgure 2: The geotechnical test equipment. (a) Compaction test; (b) cyclic compression test; (c) large direct shear test.

resilient modulus was tested after each layer was completed, and the change of the soil pressure cell was measured.

(3) The movable pavement was placed in regions 1,2 , and 3 , respectively, so that the center of the movable pavement was aligned directly above the soil pressure cell, and then, the resilient modulus was tested, and the change of the soil pressure cell on the soil surface during the resilient modulus test was recorded.

(4) Condition 1: digging $30 \mathrm{~cm} \times 30 \mathrm{~cm} \times 30 \mathrm{~cm}$ subgrade on the top of the subgrade above the soil pressure cell in the region 2 and then refilling the subgrade, so that the density of the area was lower than the surrounding, that is, setting a loose body. First, the resilient modulus of the top surface of the subgrade in region 2 was tested, and then, the resilient modulus of the three regions was tested. The change of the soil pressure cell on the soil surface during the resilient modulus test was recorded.

(5) Condition 2: digging $30 \mathrm{~cm} \times 30 \mathrm{~cm} \times 30 \mathrm{~cm}$ subgrade on the top of the subgrade above the soil pressure cell in the region 2 and then refilling the subgrade and repeating the measurement

\section{Test Results}

5.1. Influence of Different Compaction Works on Roadbed Strength. After the construction of each layer of subgrade, the resilient modulus of three regions was tested. As shown in Figure 14, it can be seen that the resilient modulus of each layer of subgrade increased with the increase of compaction times and the thickness of the subgrade. The minimum resilient modulus of subgrade was $21.41 \mathrm{MPa}$ when the first layer was compacted 4 times, and the maximum resilient modulus was 41.38 MPa when the third layer was compacted 12 times. 


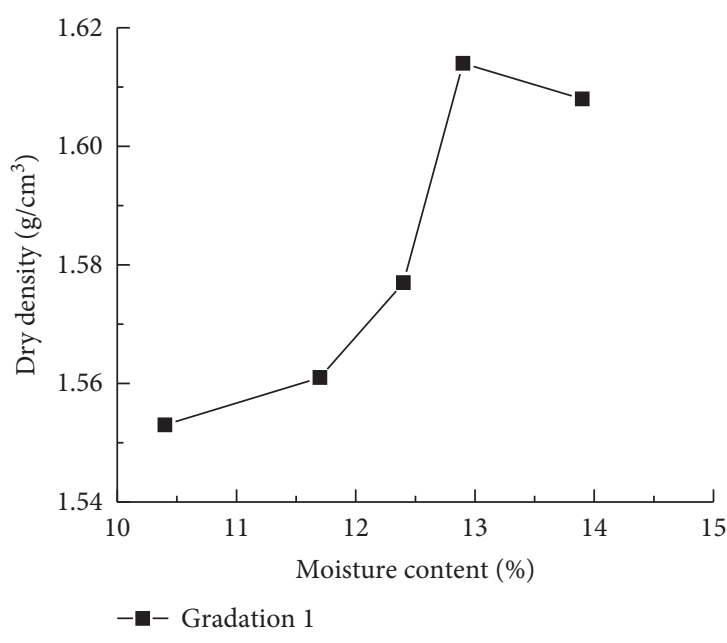

(a)

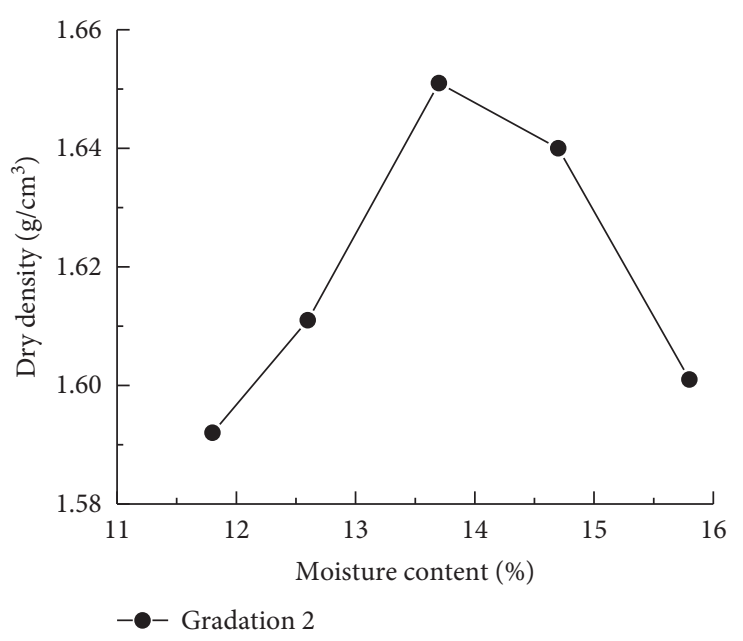

(b)

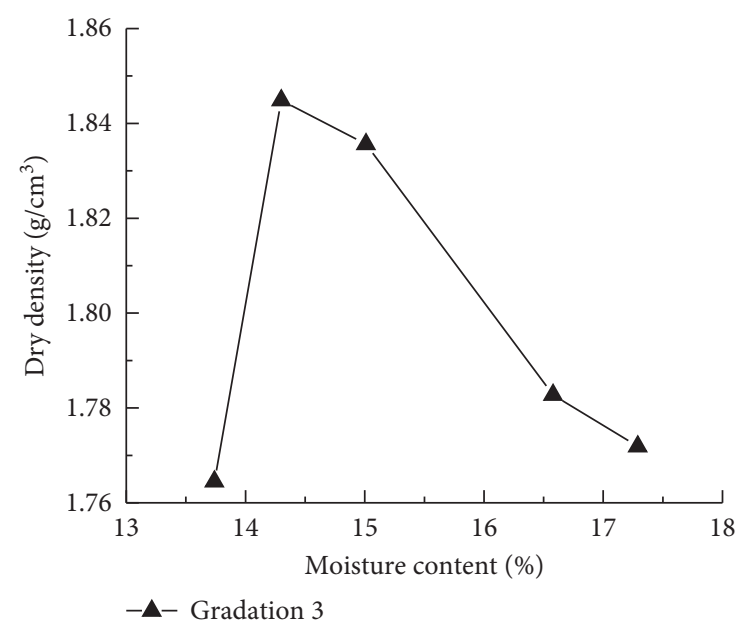

(c)

FIgURE 3: The relationship between dry density and moisture content.

Record the change of soil pressure cells changed in different regions in the process of the resilient modulus test. It was concluded that the pressure of each soil pressure cell changed with the loading in the process of the resilient modulus test.

It can be seen from Figure 15 that the change of the soil pressure had the same law after the completion of each layer of subgrade construction, that is, the increase of soil pressure in region 3 was the largest, followed by region 2 and region 1 . After the completion of the third layer, the pressure transferred from the subgrade to the soil was the smallest, that is, the thicker the subgrade was, the greater the compactness was and the smaller the pressure transferred from the subgrade to the soil was.

As shown in Figure 15(c), after the completion of subgrade, the stress transferred from the subgrade to soil was linearly distributed under the good condition of compactness. With the decrease of subgrade compactness, the stress transfer changed from linear distribution to exponential distribution, and the change rate increased. It means that in the area where the compaction was not sufficient, more stress was transferred to the lower part of the roadbed, resulting in differential settlement.

5.2. Influence of Nonuniform Roadbed on Strength. Adding the moveable pavement to the three regions, the resilient modulus test was carried out, and the loose body was set up in the region 2 to simulate the unevenness of the subgrade. The size of the loose body was $30 \mathrm{~cm} \times 30 \mathrm{~cm} \times 30 \mathrm{~cm}$ (condition 1) and $45 \mathrm{~cm} \times 45 \mathrm{~cm} \times 45 \mathrm{~cm}$ (condition 2), respectively. Then, the resilient modulus test of the subgrade in the region 2 was carried out. The test results are shown in Figure 16. As shown in Figure 16, the resilient modulus was tested in the three regions under the initial condition, and the resilient modulus was proportional to the subgrade compactness, that is, the more the compaction times were, the greater the resilient modulus was.

Due to the loose body was set on the top of subgrade in region 2 under condition 1 and condition 2 , the resilient modulus of region 2 was significantly reduced compared with the initial condition, and the resilient modulus of 


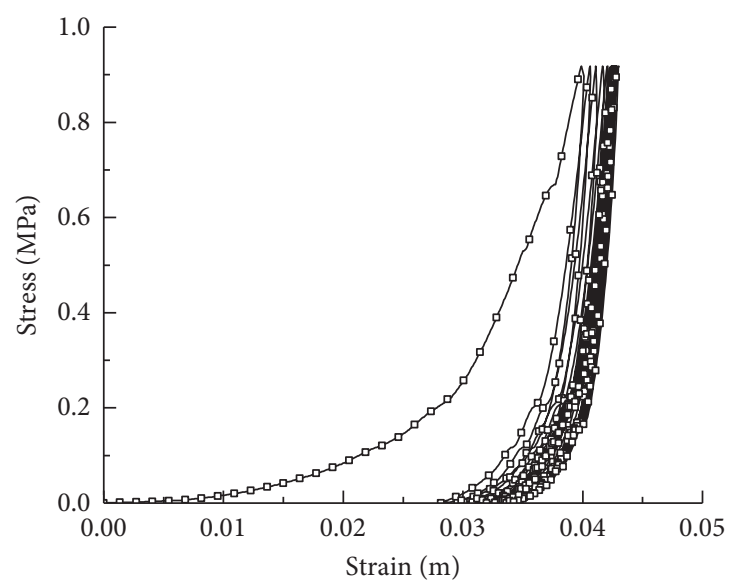

(a)

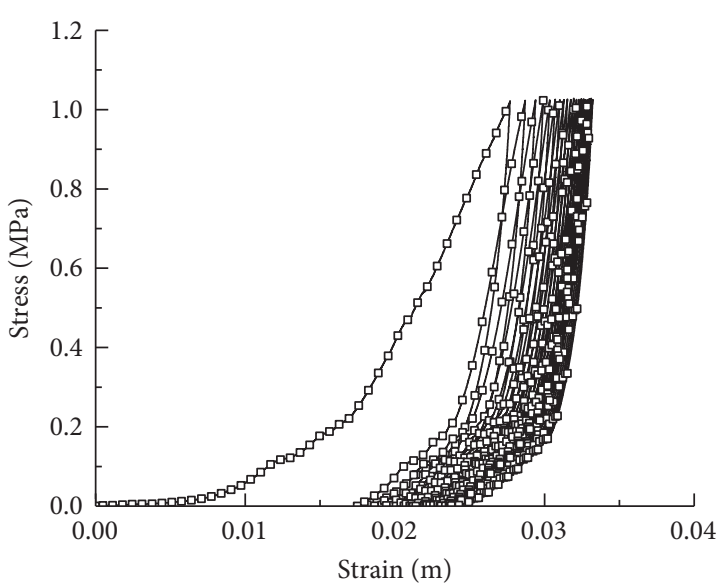

(b)

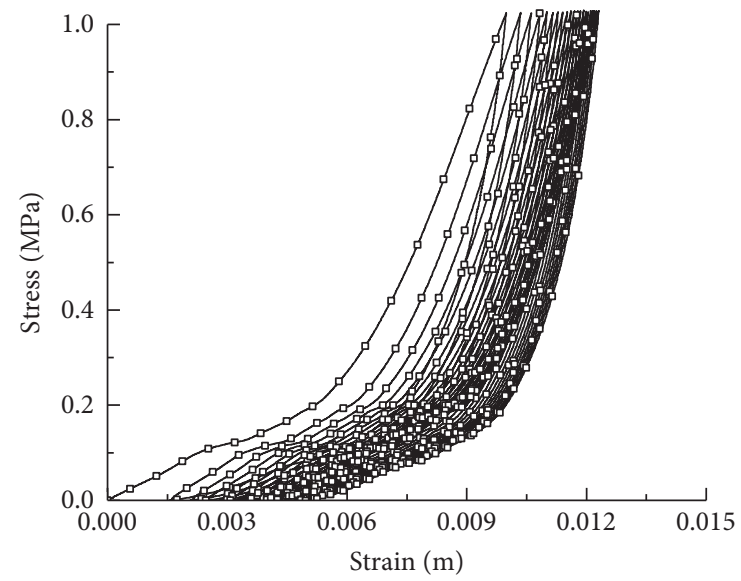

(c)

FIgURE 4: Stress-strain diagram of soil-rock mixture with moisture content =14\%. (a) Gradation 1. (b) Gradation 2. (c) Gradation 3.

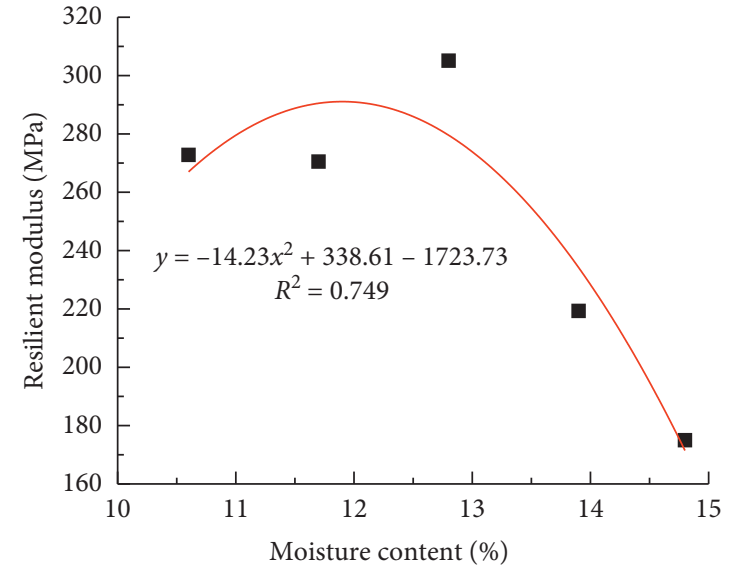

(a)

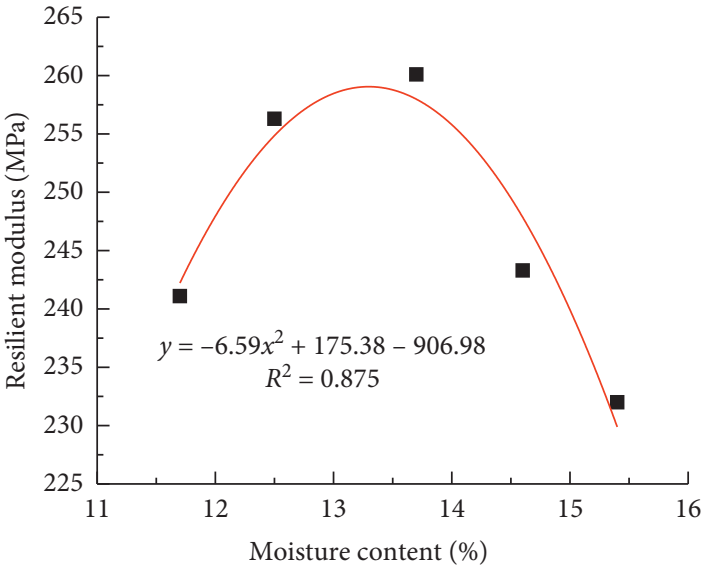

(b)

Figure 5: Continued. 


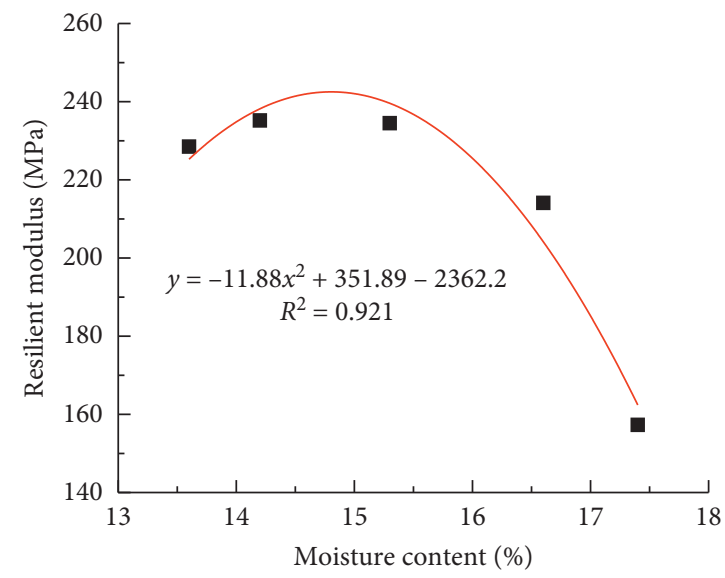

(c)

Figure 5: Relationship between resilient modulus and moisture content. (a) Gradation 1. (b) Gradation 2. (c) Gradation 3.

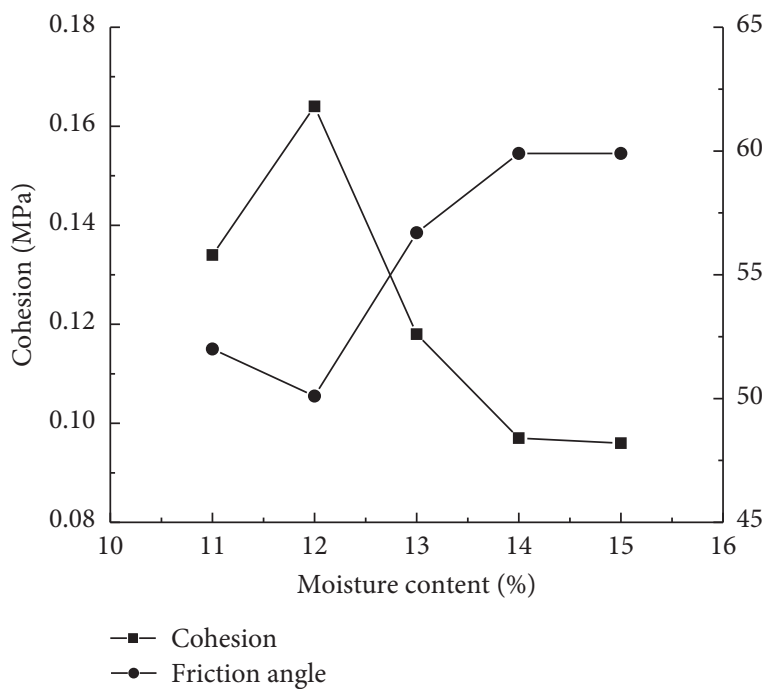

(a)

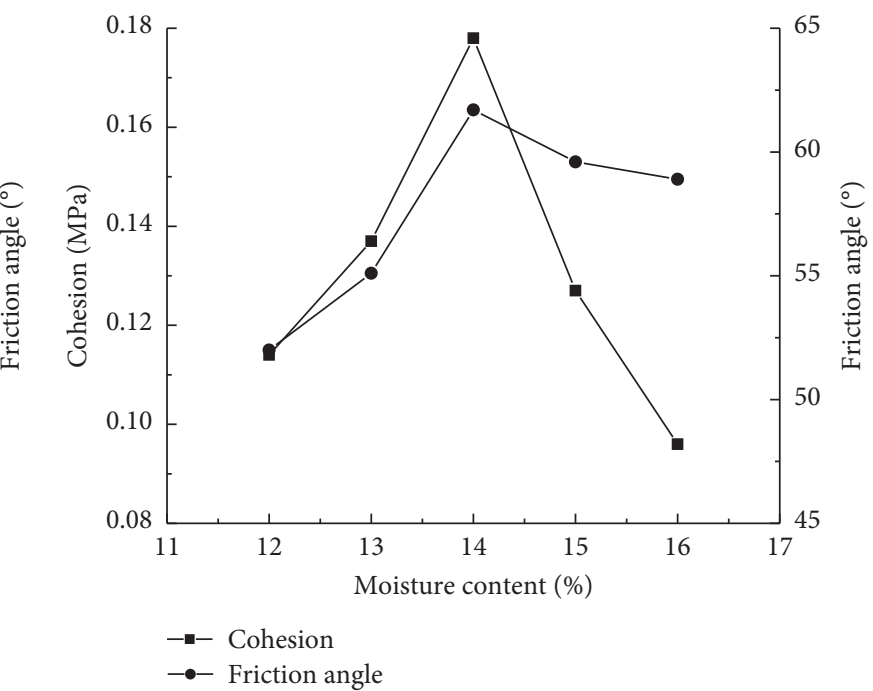

(b)

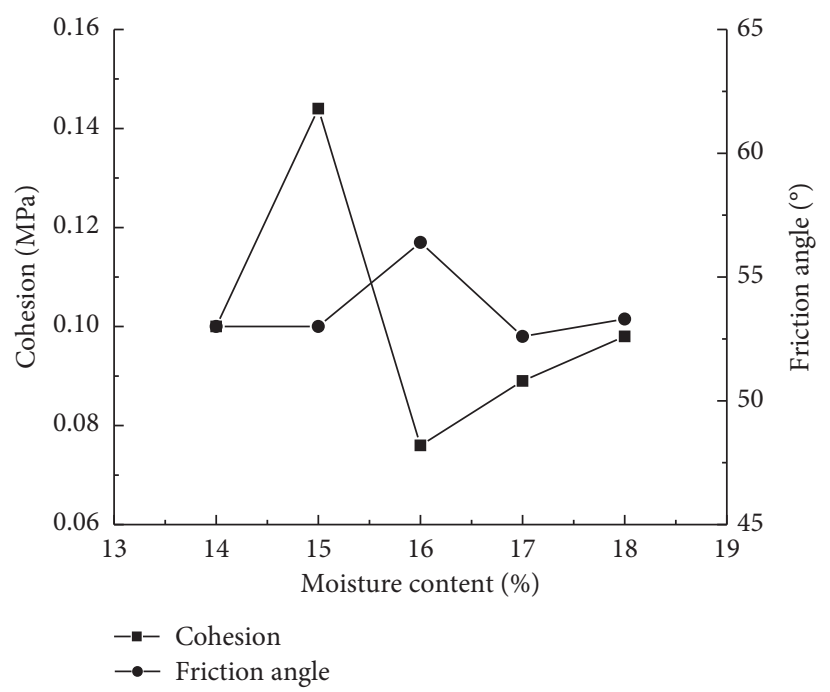

(c)

Figure 6: The variation of cohesion and friction angle of soil-rock mixture at different moisture contents. (a) Gradation 1. (b) Gradation 2. (c) Gradation 3. 


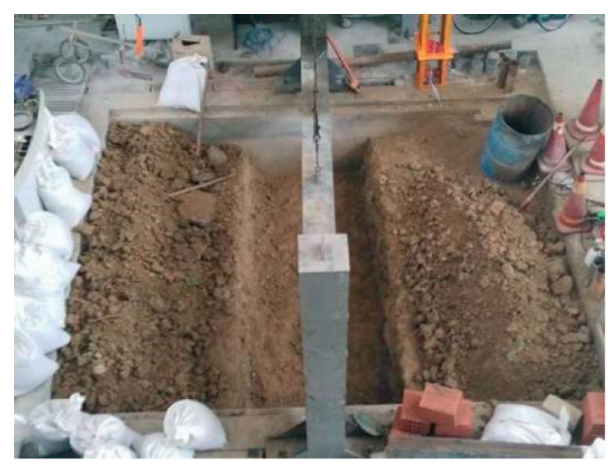

Figure 7: The site of the physical model.

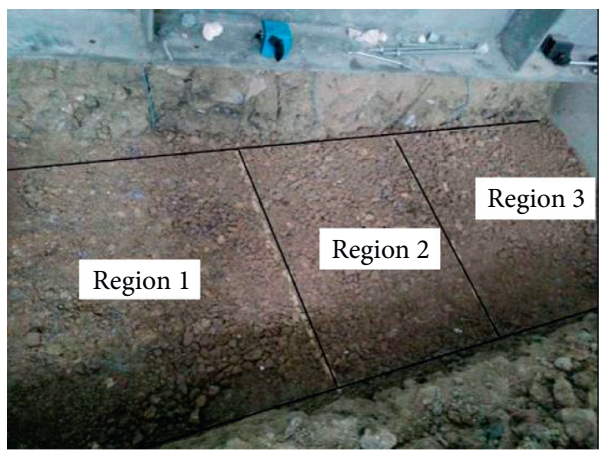

Figure 8: The division of the test area.

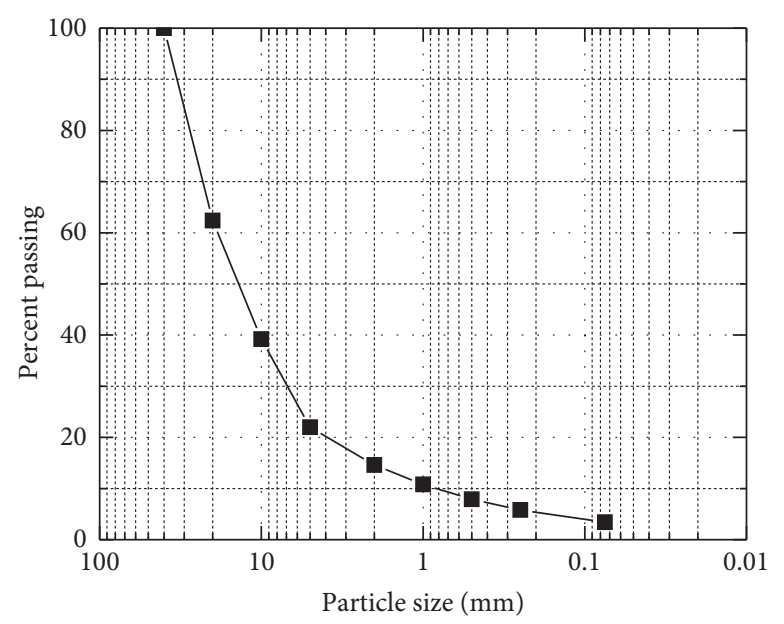

FIgURE 9: The gradation curve of soil-rock mixture.

region 1 and region 3 was also reduced, which indicated the loose body had a certain degree of influence on the surrounding area. The existence of loose body in condition 1 reduced the subgrade resilient modulus by $6.84 \%$, and the corresponding pavement resilient modulus decreased by $16.12 \%$. In condition 2 , the subgrade resilient modulus decreased by $12.98 \%$, and the corresponding pavement resilient modulus decreased by $30.15 \%$.

As shown in Figure 16, the resilient modulus of region 1 and region 3 decreased to a certain extent under condition 1 and condition 2 , but the decrease was small, and the change of resilient modulus of region 1 and region 3 was not obvious with the expansion of the loose body. The result showed that the existence of the loose body only had a significant effect on region 2 and had no significant effect on the surrounding area, which was conducive to the detection of subgrade defects.

In the process of the pavement resilient modulus test, the variation curves of soil pressure on the surface of soil foundation in region 2 under two working conditions are shown in Figure 17. It can be seen from the figure that the stress transferred from the pavement to the soil foundation 


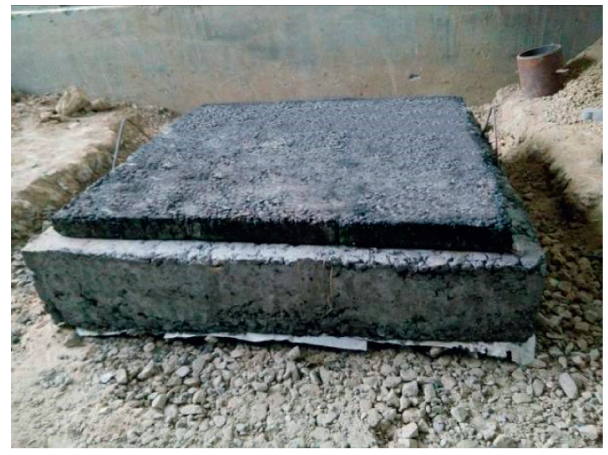

Figure 10: The movable pavement of the physical model.

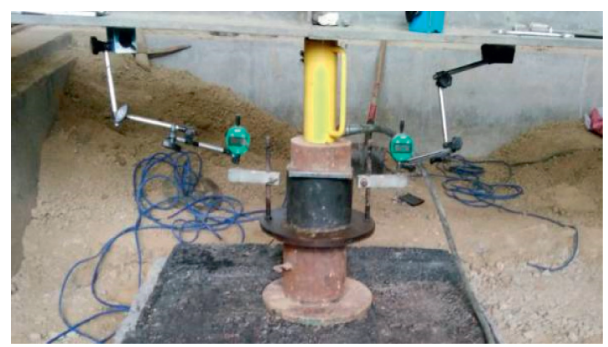

Figure 11: The equipment of the bearing plate method.

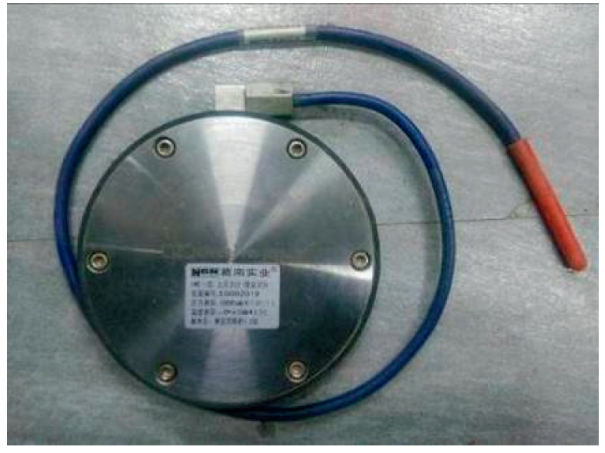

Figure 12: The soil pressure cell.

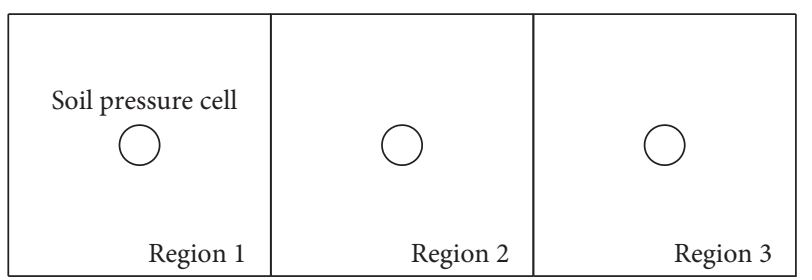

(a)

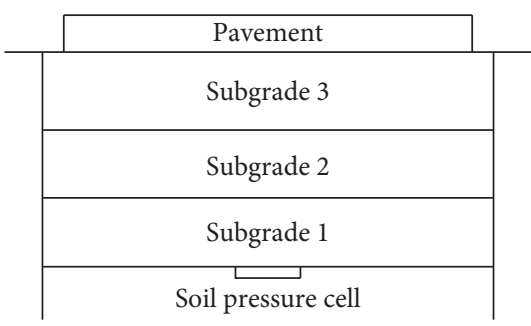

(b)

Figure 13: The arrangement of soil pressure cell. (a) The planform of soil pressure cell arrangement. (b) The profile of soil pressure cell arrangement. 


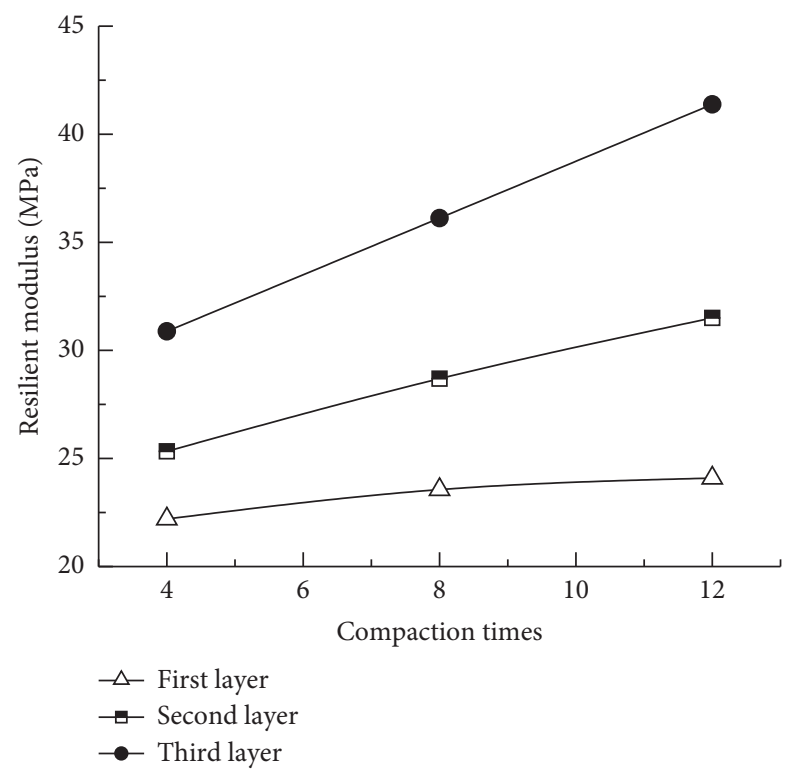

FIgURE 14: The resilient modulus changes with compaction times.
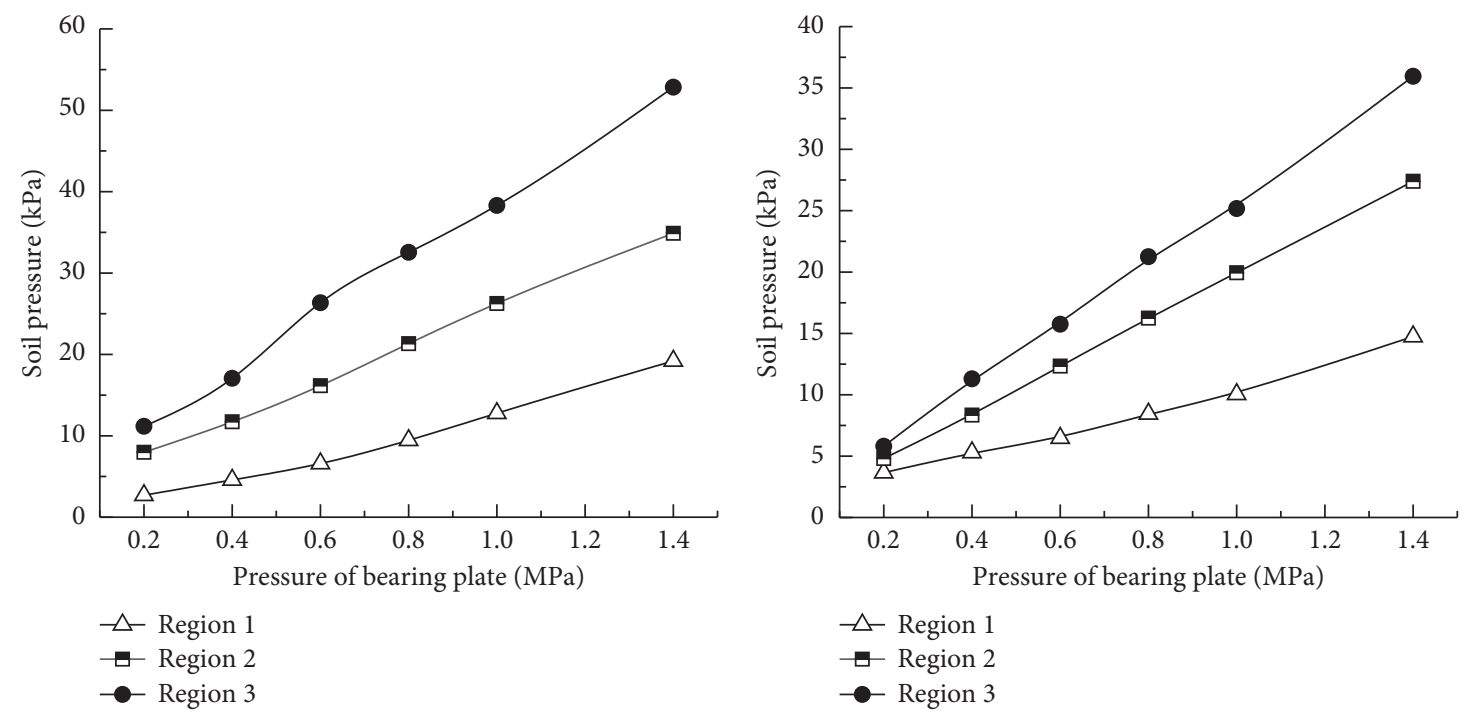

(a)

(b)

Figure 15: Continued. 


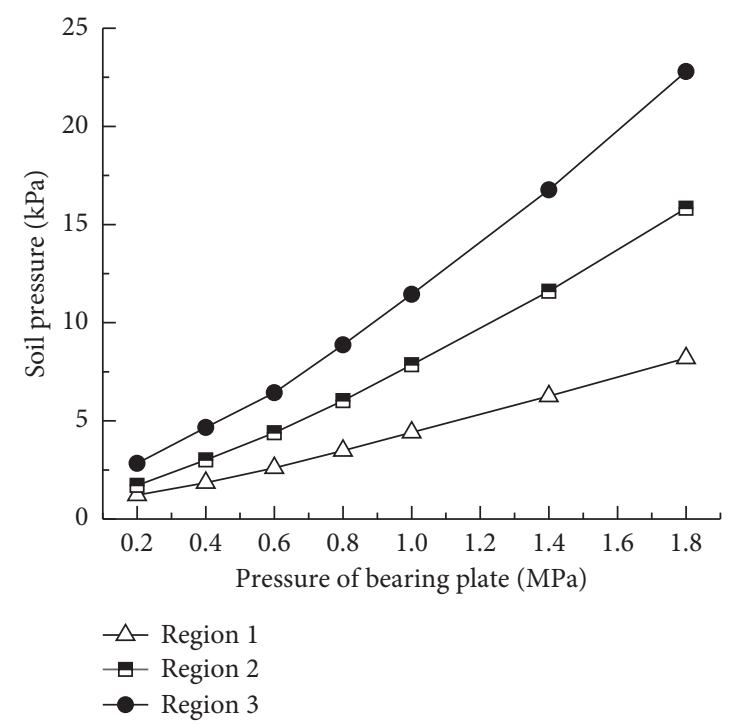

(c)

FiguRE 15: The change of soil pressure with pressure of bearing plate: (a) first layer constructed; (b) second layer constructed; (c) third layer constructed.

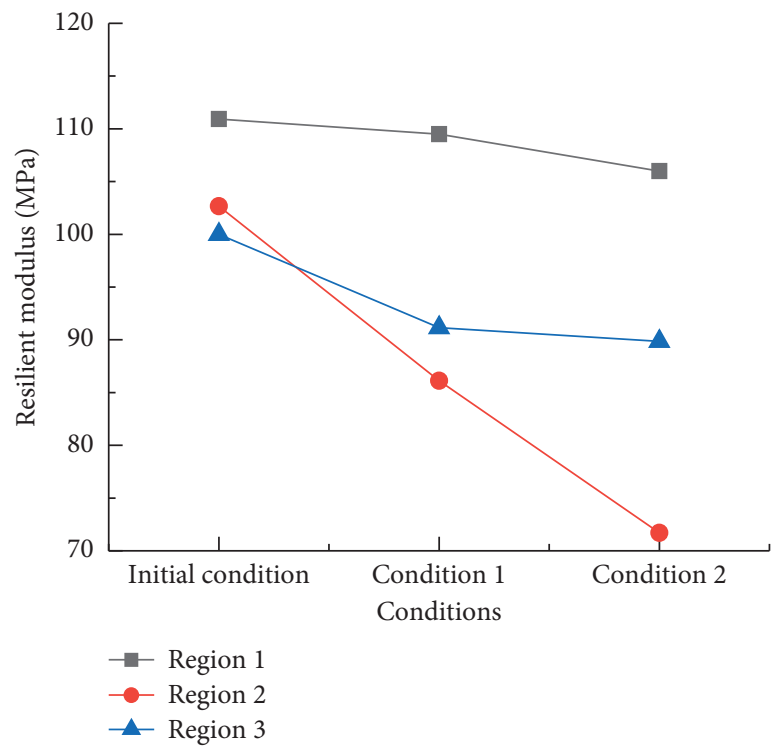

FIgURE 16: The change of resilient modulus in different regions under different conditions. 


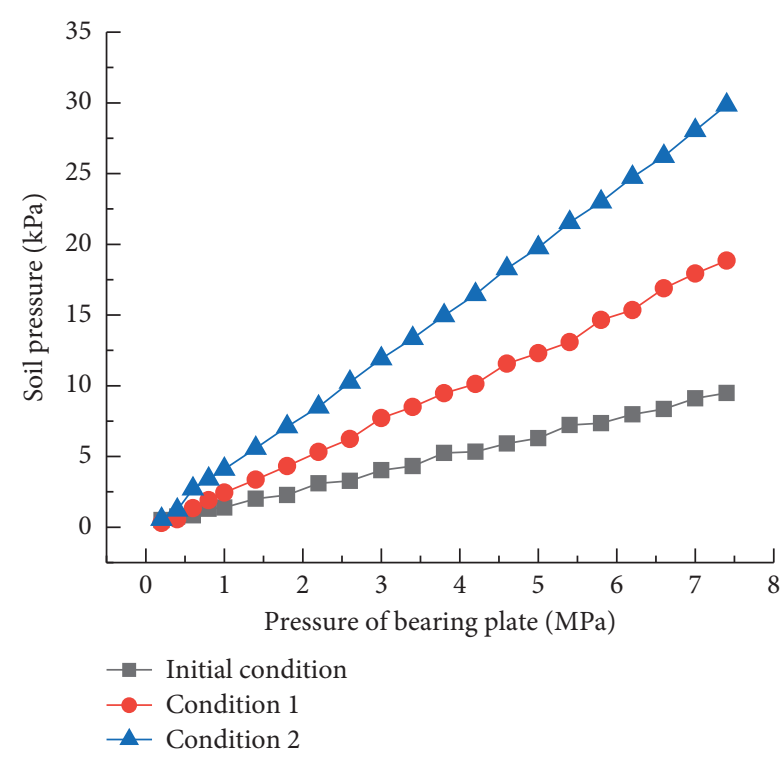

FIGURE 17: The change of soil pressure with pressure of bearing plate.

gradually increased, and the stress variation rate increased with the increase of the range of subgrade defects.

\section{Conclusions}

The study mainly analyzed the engineering characteristics of soil-rock mixture under different gradations and different moisture contents through geotechnical tests and carried out physical model to explore the influence of different compaction times and loose body on soil-mixture subgrade. The results were as follows:

(1) The gradation and moisture content had great influence on soil-rock mixture; according to the results of geotechnical tests, the engineering characteristics of gradation 2 with $14 \%$ moisture content were the best, and the soil-rock mixture was selected as the physical model material in the study.

(2) Experimental results showed that there was a positive correlation between compaction times and resilient modulus, and the stress transferred from the subgrade to soil was linearly distributed under the good condition of compactness. With the decrease of subgrade compactness, the stress transfer changed from linear distribution to exponential distribution, and the change rate increased.

(3) The existence of loose body not only reduces the modulus of resilience but also affects the stress transfer; in condition 1 , the subgrade resilient modulus reduced by $6.84 \%$, and the corresponding pavement resilient modulus decreased by $16.12 \%$. In condition 2 , the subgrade resilient modulus decreased by $12.98 \%$, and the corresponding pavement resilient modulus decreased by $30.15 \%$. The stress transferred from the pavement to the soil foundation gradually increased with the range of subgrade defects, which provided a theoretical basis for the detection and repair of subgrade defects.

\section{Data Availability}

The data used to support the findings of this study are available from the corresponding author upon request.

\section{Conflicts of Interest}

The authors declare that they have no conflicts of interest.

\section{Acknowledgments}

This research was financially supported by Science and Technology Project of Zhejiang Provincial Communication Department (2020050 and 2020051).

\section{References}

[1] L. Zheng, F. Ran, L. Chen, and S. Jianbo, "Long-term deformation of highway subgrade under coupling effect of traffic load and drying-wetting cycles," International Journal of Geomechanics, vol. 20, no. 2, Article ID 04019168, 2020.

[2] C. Tang, L. Zheng, H. Yao, and S. Guo, "Semi-analytical solution for dynamic responses of railway track system on unsaturated poroelastic half-space subjected to moving trainload," International Journal of Geomechanics, vol. 21, no. 3, Article ID 04021016, 2021.

[3] C. Tang, L. Zheng, H. Yao, S. Guo, and Y. Han, "Vibration characteristics of unsaturated runways under moving aircraft loads," International Journal of Structural Stability and Dynamics, vol. 21, no. 5, Article ID 2150065, 2021.

[4] M. Zhao, G. Liu, and L. Deng, "Optimizing the compaction characteristics and strength properties of gravelly soils in terms of fine contents," Advances in Materials Science and Engineering, vol. 2021, Article ID 6634237, 18 pages, 2021.

[5] X. Ling, P. Li, F. Zhang, Y. Zhao, Y. Li, and L. An, "Permanent deformation characteristics of coarse grained subgrade soils under train-induced repeated load," Advances in Materials Science and Engineering, vol. 2017, Article ID 6241479, 15 pages, 2017.

[6] S. Wang, T. Ji, Q. Xue, Z. Shen, and Q. Zhang, "Deformation and failure characteristics of soil-rock mixture considering material composition and random structure," Advances in Materials Science and Engineering, vol. 2019, Article ID 3165096, 13 pages, 2019.

[7] P. Shan and X. Lai, "Mesoscopic structure pfc2d model of soil rock mixture based on digital image," Journal of Visual Communication and Image Representation, vol. 58, pp. 407415, 2019.

[8] L. Zheng, C. Tang, Y. Duan, R. Fang, H. Yao, and S. Guo, "Field test and semi-analytical simulation of unsaturated road subgrade in various water content subjected to a heavy duty truck," Soil Dynamics and Earthquake Engineering, vol. 144, Article ID 106667, 2021.

[9] N. Zhao, Y. Wang, B. Meng, and N. Luo, "Numerical simulation on the seepage properties of soil-rock mixture," Advances in Materials Science and Engineering, vol. 2018, Article ID 1859319, 10 pages, 2018.

[10] M. Afifipour and P. Moarefvand, "Experimental study of postpeak behavior of bimrocks with high rock block proportions," 
Journal of Central South University, vol. 21, no. 2, pp. 761-767, 2014.

[11] L. E. Vallejo, "Interpretation of the limits in shear strength in binary granular mixtures," Canadian Geotechnical Journal, vol. 38, no. 5, pp. 1097-1104, 2011.

[12] Y. Wang, X. Li, and B. Zheng, "Experimental study on the non-Darcy flow characteristics of soil-rock mixture," Environmental Earth Sciences, vol. 75, no. 9, pp. 1-18, 2016.

[13] W. J. Xu, Q. Xu, and R. L. Hu, "Study on the shear strength of soil-rock mixture by large scale direct shear test," International Journal of Rock Mechanics and Mining Sciences, vol. 48, no. 8, pp. 1235-1247, 2011.

[14] H. F. Zhao and L. M. Zhang, "Effect of coarse content on shear behavior of unsaturated coarse granular soils," Canadian Geotechnical Journal, vol. 51, no. 12, pp. 1371-1383, 2014.

[15] D. Cen, D. Huang, and F. Ren, "Shear deformation and strength of the interphase between the soil-rock mixture and the benched bedrock slope surface," Acta Geotechnica, vol. 12, no. 2, pp. 391-413, 2017.

[16] Y. Hao, Z. Zhong, W. Xiangcan, and Z. Qifang, "Elastic modulus calculation model of a soil-rock mixture at normal or freezing temperature based on micromechanics approach," Advances in Materials Science and Engineering, vol. 2015, Article ID 576080, 10 pages, 2015.

[17] W. J. Xu, C. Q. Li, and H. Y. Zhang, "DEM analyses of the mechanical behavior of soil and soil-rock mixture via the $3 \mathrm{D}$ direct shear test," Geomechanics and Engineering, vol. 9, no. 6, pp. 815-827, 2015.

[18] W. J. Xu and H. Y. Zhang, "Research on the effect of rock content and sample size on the strength behavior of soil-rock mixture," Bulletin of Engineering Geology and the Environment, vol. 80, no. 2, 2021.

[19] B. Li, "Study on shear properties of the soil-rock mixture," E3S Web of Conferences, vol. 165, no. 7, Article ID 04079, 2020.

[20] H. Soliman and A. Shalaby, "Permanent deformation behavior of unbound granular base materials with varying moisture and fines content," Transportation Geotechnics, vol. 4, pp. 1-12, 2015.

[21] M. H. Zhao, J. J. Liu, H. Luo, and M. H. Yang, "Experimental studies of shear strength characteristics and influencing factors of soil-rock aggregate mixture," Rock and Soil Mechanics, vol. 38, no. 4, pp. 965-972, 2017.

[22] R. L. Mokwa and N. R. Trimble, "Permeability of coarsegrain soil from void space and pore distribution," in Proceedings of the GeoCongress 2008: Characterization, Monitoring, and Modeling of GeoSystems, pp. 428-435, New Orleans, LA, USA, March 2008.

[23] W. J. Xu, L. M. Hu, and W. Gao, "Random generation of the meso-structure of a soil-rock mixture and its application in the study of the mechanical behaviors in a landslide dam," International Journal of Rock Mechanics and Mining Sciences, vol. 86, pp. 166-178, 2016.

[24] G. J. Wang, X. Y. Kong, and Y. L. Gu, "Numerical simulation of triaxial tests for coarse-grained soil considering the initial fabric of samples grain," Advanced Materials Research, vol. 143-144, pp. 873-878, 2011.

[25] H. Z. Wei, W. J. Xu, C. F. Wei, and Q. S. Meng, "Influence of water content and shear rate on the mechanical behavior of soil-rock mixtures," Science China Technology Science, vol. 61, no. 8, pp. 1127-1136, 2018.

[26] H. Z. Wei, W. J. Xu, X. F. Xu, and Q. S. Meng, "Mechanical properties of strongly weathered rock-soil mixtures with different rock block contents," International Journal of Geomechanics, vol. 18, no. 5, Article ID 04018026, 2018.
[27] X. M. Zhang, Y. Z. Lv, Q. Dong, and Y. H. Zhang, "Evaluating compaction quality of soil-rock mixture based on theory of elastic waves," Chinese Journal of Geotechnical Engineering, vol. 37, no. 11, pp. 2051-2057, 2015.

[28] D. Q. Zhou, C. Deng, D. L. Li, and Y. Zhou, "Experimental study for soil-rock mixture about deformation law and correlation between compaction indexes under repeated compression-rebound," Journal of Central South University (Science and Technology), vol. 49, no. 12, pp. 3077-3086, 2018.

[29] Q. Guo, "Discussion on engineering characteristics and classification of coarse-grained soil," Water Resources and Hydropower Engineering, vol. 11, no. 6, pp. 53-57, 1979, (in Chinese). 